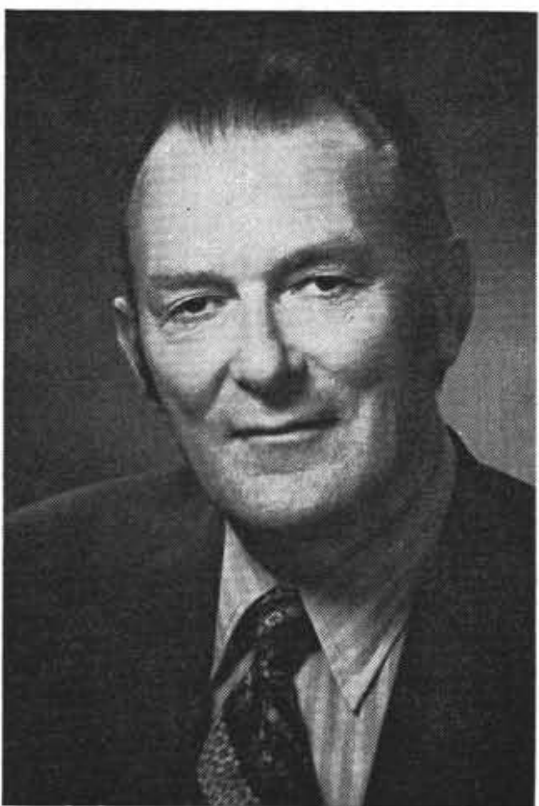

A. B. Anderson President

\section{President's Report}

This is the last column I will be writing as your President. Fortunately I am able to conclude on a positive note regarding one important matter: namely, progress toward a national forest policy.

It was long ago, in March 1925, that C. D. Howe the then President of our predecessor, the Canadian Society of Forest Engineers, spoke before the Royal Canadian Institute in Toronto. He said, in part: -

"A definite forest policy... should be publicly declared and financially sustained... It is the function of the Federal Government to take the leadership in the formulating and the sustaining of such a policy."

What has happened in the interval I do not know. It is easy to imagine that this matter came up time after time - I know this was true in 1970 when Gerry Burch expressed concern over the lack of such a policy. However it was not until 1973 that the CIF/IFC successfully perceived itself as a vehicle for promoting the development of a national forest policy. Then, in 1974, and almost simultaneously, three groups expressed strong views on the matter to the Federal Government: a forest management group of the CPPA, the Canadian Forestry Advisory Council, and our Institute. Under the leadership of Dr. Gordon Weetman, the CIF/IFC, as a politically neutral body with a nation-wide range of forest expertise, proposed to undertake a study for the purpose of developing a national forest policy. The study was to be made by Dr. Peter Pearse.

To obtain the financial support necessary the proposal was put before the Department of Supply and Services and the Ministry of State for Science \& Technology. Endorsed in principle, the project was none-the-less rejected as the Federal Government was of the opinion that such a policy could be developed best under its own sponsorship. Subsequently in March 1975 Dr. Phil Thomas was appointed to establish a basis for the development of a national forest policy.

Dr. Thomas worked hard on this project until his retirement in mid-1976, when he was succeeded by Dr. Cam Place. About the same time, the provinces, who had been alerted to the federal study, became involved when the development of the proposal was allocated to the Canadian Council of Resource \& Environment Ministers (CCREM). The first full meeting was held in Winnipeg in September 1976 and the second in Saskatoon in June 1977. At the latter meeting the proposal to develop a national forest policy was finally approved. The die has been cast. It is now a question of method and time until we have that which we knew we must have at least 52 years ago!

Initially the development of the national forest policy will be limited to two phases: first, the status of the resource; and second, the protection and enhancement of the forest estate. The former will consist of an assessment of the resource and its use, all in broad terms; and the latter will be similarly described and defined.

There are at least three aspects of the foregoing which concern your Executive Committee.

First. We still believe it would have been preferable to have had a study and development of a new policy through the efforts of a non-political organization of forestry expertise such as our Institute. Because of the course adopted, the very sensitive matter of provincial jurisdiction has always been evident, has always had over-riding consideration, and has consequently resulted in a withdrawal of the original federal drive to a more subdued position. Discrete and careful moves by federal representatives, and by some provincial representatives, have refused what could have been a divisive factor so that now we have a fairly relaxed approach by the provinces. All this has been necessary, but is it necessarily going to produce the best results? We can only hope that it will.

Second. Your Executive Committee is worried over the complete lack of association, industry and academic participation in developments to date. At both CCREM meetings there was no repre. 
sentation other than from the eleven governments. At the Saskatoon meeting there was general agreement on the need for extensive involvement of the private sector, but how this is to be accomplished was not decided. Despite strong advocacy for outside involvement by Phil Thomas, Cam Place, Bill Young and others, there is no sign of it yet. The CIF/IFC has been promised representation on the Steering Committee but this has not materialized. Subsequent to the Saskatoon gathering, a meeting of forestry officials was held in Toronto. They set up a Steering Committee of a federal representative and the ten provincial forest deputy ministers; and they set up an Executive Committee consisting of the Deputy Ministers of New Brunswick, Ontario, Alberta, British Columbia and the Federal Government. The latter committee will plan future work. If the Institute is to be involved, as it must be, then we should continue to press. It is my personal belief, that apart from representation on the Steering Committee, we should enjoy representation on most, if not all, future working committees \& sub-committees. Our broad and varied expertise would be beneficial. At the same time as pressing for our own involvement we should be pressing equally as energetically for involvement of the private sector generally.

Third. When positive proposals were first made in 1973 and 1974, a number of foresters questioned their necessity: "Why bother", they asked, "have we not gotten along without a policy in the past?" This view persists. We hope it will not grow. We hope it will not discourage further effort. In expressing this concern I do not want to convey the impression that this negative attitude is present in the CCREM organization or the Steering Committee of forest deputies. It is not. Of the eleven governments, ten are determined to proceed albeit with varying degrees of enthusiasm - only Quebec is holding back, and it is not adopting an obstructive attitude, but rather is attending as an observer.

In expressing these concerns your Executive Committee does not want to create an atmosphere of pessimism. For the first time in 52 years positive steps toward the development of a national forest policy have been made. It is on a firm footing, it is funded, it has been strongly supported by most of those involved, and it has been promoted by The Honourable Roméo LeBlanc in his statements before the Standing Committee on Fisheries \& Forestry in Ottawa. Progress will continue, but the private sector must be involved - our Institute must be involved. We must give strong support and respond actively to any request made of us. The CIF/IFC has the capacity to play an important role in the development of our National Forest Policy and we should ensure that it does.

\section{Correction}

An error occurred in the President's report in the August issue. In the excerpts from the Minister's statement to the Standing Committee on Fisheries and Forestry, under Specific program items, the second paragraph should read:

"Canada does need a national focus for ongoing analysis and development to ensure that provincial and federal actions and policies affecting the use and management of the forest resource are consistent and in accord with the long term needs."

The President apologizes to the Minister, and to the readers for this unfortunate lapse.

\section{J. D. MacArthur}

\section{Why Urban Forestry?}

Urban forestry, being a new venture for the Canadian forestry profession, has potential for contributing a number of essential benefits to Canadians of all walks of life, as well as to forestry itself.

The questions in the minds of most professional foresters have been and probably still are: "What is it?" or "Why urban forestry?".

In 1974 the CIF established an Urban Forestry Working Group (W.G. \#12) for the purpose of providing some answers to these questions. The first meeting of W.G. \#12 was held in connection with the CIF Annual Meeting at Niagara Falls in 1974 and every year since a small group of foresters dedicated to urban forestry have met on the occasion of the Annual Meeting. At the 1976 CIF Annual Meeting in Thunder Bay, W.G. \#12 enjoyed a visit to the local municipal parks system, followed by a short business meeting. At this meeting it was decided that one way of attempting to answer some of the professional foresters questions relating to urban forestry would be to collect a group of papers for a special edition of The Forestry Chronicle dedicated to the topic of urban forestry. The results of this effort are to be found on the following pages and it is sincerely hoped that the papers selected will provide a number of answers to the above questions.

The papers presented by individual authors provide an insight in some of the urban forestry activities presently taking place in Canada, but are not to be thought of as a state of the art presentation. Presently the active participants in the Urban Forestry Working Group are a very small number of people representing in particular the Provinces of Quebec, Ontario and British Columbia and, should you through reading the papers, become interested in joining the Working Group, I can assure you that we need your initiative and support and that you shall be most welcome.

Urban forestry is basically community-oriented forestry which has as its main purpose the optimization of the human living environment through 
appropriate vegetation management of urban and peri-urban trees and forests. The practice of urban forestry is not solely the privilege of major cities and towns, but also a need facing small communities. The latter point has been well documented by the Urban Forestry Working Group initiative with regard to Resolution 76.2 passed by the 1976 Annual Meeting in Thunder Bay, and dealing with a concerted program of selecting and testing of native and exotic tree species for amenity planting for the benefit of present and future northern communities. The provincial responses to this Resolution were, as a whole, most heartening, showing that an urban forestry need indeed exists in smaller northern communities and that an initiative on the part of foresters would be most useful and welcome.

I hope you will exert your influence and utilize your experience for the benefit of your local community and that you will join us in the CIF Urban Forestry Working Group for an exchange of your experiences.

\section{Erik Jorgensen \\ Chairman, CIF \\ Urban Forestry Working Group \#12}

\section{Response to Urban Forestry Resolution: 76-2}

Resolution 76-2, which drew the attention of government authorities to a need for research on trees for amenity planting in northern communities, appeared in the August issue. At that time President Anderson reported on action on the resolution, and response to that action. The six letters of substance which he mentioned are now available for publication and are included here as part of this Urban Forestry issue.

\section{Dear Mr. Anderson:}

Thank you for your letter of January 3, 1977 on the subject of selecting and breeding trees for amenity planting in northern communities. I agree that this is an important problem which is receiving little attention. Indeed I am told that most of the trees used for ornamental planting and landscape gardening in Canada as a whole originate in the United States and that we are making little use of the potential wealth of Canadian trees and shrubs for this purpose.

As you probably know, the Canadian Forestry Service does have a considerable program in tree breeding, which is particularly active in British Columbia, Ontario and the Maritimes. Most of the effort of this program is being devoted to conifers for commercial forestry use. The provenance work on spruces and pines, however, includes much material from the Boreal forest that might be of use in northern communities. We have also recently started a small program at the Petawawa Forest Experiment Station on breeding of broad-leaved species for amenity use. The Canada Department of Agriculture also conducts a program on shade trees and shrubs, although not with northern communities specifically in mind.

To the best of my knowledge, the PFRA tree nursery at Indian Head, Saskatchewan, is the only nursery directing its tree breeding efforts to producing trees and shrubs suitable for harsh prairie and northern environments. This organization belongs to the Department of Regional Economic Expansion. It may interest you to know that the Canadian Council on Rural Development will probably recommend a sharp increase in its support by DREE.

Although I am sympathetic to the CIF's recommendation, the present financial constraints will not allow the Canadian Forestry Service to expand its tree improvement programs further to meet the needs of northern communities in the next few years. If the economic situation improves I will reexamine your proposal to determine what role the CFS might play.

\section{Minister, Fisheries and Environment Canada}

\section{Moinsieur le Président:}

Votre lettre du 17 janvier 1977 a été lue très attentivement et je tiens à féliciter l'IFC pour cette initiative qui démontre ses préoccupations sociales.

Comme vous devez le savoir, le ministère des Terres et Forêts du Québec est engagé depuis 1969 dans la création d'un réseau d'arboretums à travers le territoire du Québec. A ce jour, dix-huit arboretums et deux populetums ont été installés dans lesquels se poursuivent des essais d'introduction d'espèces, des tests de provenances, de descendances et de clones ainsi que la réalisation de verges à graines.

Dans les arboretums, quelque 57 espèces exotiques ont été essayées dont une quinzaine montrent un comportement intéressant.

L'un des arboretums, installé sur les abords de l'autoroute $n^{\circ} 20$, est spécialement développé pour la sélection d'espèces aptes à l'ornementation des routes et autoroutes et résistantes au sel.

L'arboretum situé le plus au nord se trouve à Chibougamau et les résultats qui y seront obtenus pourront dans une certaine mesure être appliqués à certaines régions encore plus septentrionales.

La résolution de I'IFC correspond à un besoin réel. Cependant, il faut tenir compte des disponibilités budgétaires et de la vocation prioritaire du Ministère. De plus, même si les budgets étaient disponibles, une difficulté majeure resterait à surmonter. Les essais d'espèces ornementales pour les régions très septentrionales supposent la disponibilité de matériel biologique (grainés et autres) provenant de régions ou de niches écologiques souvent éloignées des voies d'accès et où la récolte de matériel sera très coûteuse.

La solution la moins coûteuse pour l'instant est d'exploiter les espèces indigènes locales et aussi celles provenant de latitudes plus méridionales mais de régions adjacentes. Environ une douzaine 
d'espèces d'arbres indigènes et quelques espèces exotiques pourraient être utilisées pour l'ornementation des villes septentrionales situées jusqu'au niveau de la taïga. II va de soi qu'une expérimentation systématique permettrait à plus ou moins long terme d'élargir le nombre d'espèces d'arbres. d'arbustes et de plantes ornementales pour ces régions.

Nous croyons qu'un programme de ce genre, même limité, sera à la longue assez onéreux, en partie à cause de l'éloignement de ces régions. Compte tenu de ce fait, il faut se demander sérieusement s'il concorde avec les priorités d'un ministère chargé de la gestion des forêts publiques ou même s'il pourrait concorder avec celles d'un ministère responsable de la qualité de l'environnement, vu qu'il existe tellement d'endroits où l'environnement est beaucoup plus dégradé que celui de localités septentrionales.

Je profite de l'occasion pour féliciter les membres de votre Institut pour l'attention qu'ils accordent à l'intérêt public. Veuillez leur transmettre, Monsieur le Président, mes cordiales salutations.

Yves Bérubé Le ministre des Terres et Forêts, Québec.

\section{Dear Mr. Anderson:}

The resolution of your recent Annual Meeting concerning the testing and selecting of trees suitable for amenity planting in Northern Communities has been discussed by my staff. We are sympathetic to the situation and agree that northern communities have a very limited number of species available for this use. As well, the sources of material propagated by the majority of the Ontario commercial trade are from southern Ontario, the United States or other more moderate climates.

Our involvement in amenity species is relatively small. Our tree breeding and tree improvement program is directed to the commercial timber species and in the north, is limited to spruce, pine and poplar. If interesting trees are discovered however, they are held for display in a recently established arboretum at the St. Williams nursery.

While our staff and facilities are limited, we have in the past given financial assistance to urban forest projects. Until recently we gave financial assistance to the Shade Tree Laboratory at the University of Toronto in their work of selecting cultivars for urban forestry use. If other such proposals were received by this Ministry, they would be favourably considered.

While we understand this problem related to amenity species, we cannot foresee any further extension of our direct involvement in the near future.

Frank S. Miller Minister of Natural Resources, Ontario

\section{Dear Mr. Anderson:}

The Forest Research Section of the Department of Renewable Resources and Transportation Services is currently engaged on an active and dynamic tree improvement program to produce genetically superior seeds for the commercial reforestation of all burnt and cut-over lands in the Province of Manitoba. It is hoped that an adequate and abundant supply of high quality seeds of both native and exotic species would be available by 1990 .

The testing of exotic species for wood hardiness, weather and disease resistant characteristics and good stem form is now in the infancy stage. The exotic species under consideration are Siberian Larch, Russian Scots Pine (Pinus sylvestris L.), Pinus koriensis, Norway Spruce, Larix gemelini and Pinus sylvestris var. Mongolica. Most of them have been planted in the Pineland Research Nursery field \#28 and some are in FH 315 containers. More seeds of different provenances are expected to arrive from China and Russia, sometime this year, for further testing and selection of suitable provenances that would grow under Manitoban climate.

The native species under test is the hybrid Populus 44-52. Results of trials of this hybrid over a period of eight years indicate a very favourable growth with good stem form as well as weather and disease resistant characteristics on certain sites. Extensive trials of this hybrid would be carried out commencing from this year. Details of growth to date could be obtained from the Departmental publication Information Bulletin 3-1976.

The first phase of clonal seed orchards would be established in the Province, with white spruce (Picea glauca (Moench) Voss) in 1979/80. Vegetative propagation techniques of grafting and rooting have been carried out since 1976. These orchards would be established by grafts until our trials of cuttage shed some light on the time period between the rooting of cuttings and seed production. Initially ten acres would be established in the vicinity of Sprague (NE 1/4 Section 19, Township 1, Range 14E), Additional information is available from the Departmental Information Bulletins 1 and 2 of 1976.

Provenance trials of three species, white spruce, black spruce, and jack pine in the province would establish criteria of:

1. Seed movement and transfer

2. Seed zonation

3. Adaptability over variant ecogeographic ranges.

The results from these composite trials could serve as a basis for the selection of suitable species for amenity planting in the harsh climate in accordance with the resolution of the Canadian Institute of Forestry.

\section{Hastrom} Minister of Renewable Resources and Transportation Services Manitoba

\section{Dear Mr. Anderson:}

Thank you for bringing to my attention the Resolution regarding amenity plantings passed at your 68th Annual Meeting.

My Department is not directly involved in the selection and testing of native and exotic tree 
species for amenity plantings in communities. However, during the mid to late 1960's we had a very intensive afforestation program in recreation areas in the southern part of our province. Trees were planted in highway picnic sites, Trans Canada Campgrounds, Provincial Parks and Regional Parks. The purpose of the planting was to provide shade and a pleasant visual effect on our open wind swept environment. Some planting locations were very tough and we had our successes and failures. Both native and exotic trees were used and from those early plantings we now have a sound basis on which to select hardy species.

I realize that our experience does not relate directly to your concern about plants for communities, however I feel we have contributed something to the knowledge of amenity plantings.

Thank you again for bringing this matter to my attention.

Adolph S. Matsalla

Minister of Tourism and Renewable Resources Saskatchewan

\section{Dear Mr. Anderson:}

I have received your letter of January 3rd recommending a program to develop suitable tree species for amenity planting in northern towns and cities.

The Alberta Forest Service has recently established a modest tree improvement program. One of its objectives is to develop hardy planting stock suitable for northern locations. Some work is also underway to test introduced tree species for hardiness under northern conditions.

I believe that this work will contribute directly towards the development of suitable stock for the very important purpose of municipal beautification.

Thank you for advising me of your views on this matter.

Minister of Energy and Natural Resources

Alberta

\title{
Policemen, Planners and Managers, in New Brunswick Crown Forests ${ }^{1}$
}

\author{
G. F. Weetman
}

New Brunswick, like Ontario, Quebec and Manitoba, has chosen to attempt to fill, simultaneously, the roles of policeman, planner and manager of forested Crown lands. The wisdom of assuming the third role - the manager - is questionable. It is indeed doubtful whether the Province is either financially or physically capable of doing the job effectively on all Crown lands. It is worth noting that, while Ontario opted for this approach in 1962, in spite of the opposition of some dedicated government foresters, the Armson study of 1975 recommended that responsibility for forest management be handed back to industry (1).

Superficially, the arguments for government management appear logical. The forests belong to the public and the public interest must be protected. The environment must be preserved or enhanced, and wood resources rationed on the basis of allowable-cut calculations and socio-economic factors. Moreover, the continued productivity of Crown forest land must be assured and, when cut, the land must be promptly and adequately regenerated (2). Large industrial corporations do not necessarily share the same priorities and, therefore, all of these roles should be played by government. It sounds reasonable, particularly

1Reprinted from UNB Forestry Focus, a quarterly publication of the Faculty of Forestry, University of New Brunswick. when the forest-management track record of large pulp and paper companies, operating on leased Crown lands in eastern Canada, is examined.

However, the situation is not simple and the apparent solution - government management - is not necessarily the best.

Historically, Crown forests were regarded as unused resources waiting to be exploited to create jobs and wealth. Assignment of timber leases was generous - so generous, in fact, that wood supplies were in general, more than adequate for industrial needs. The logical roles of the Crown as policeman and planner were largely unfulfilled as there was little to police or plan for in an era when the objectives were to cut the forest and create jobs. Environmental and social issues were not yet recognized. It was an era marked by a lack of both on-the-ground management and forest-management objectives. If any forest management was needed - and apparently little was - it was left up to the industry.

We are now in another era in New Brunswick. The budworm crisis has forced the Government into the decision-making role in forest protection. It has also forced an appraisal of long-term timber supply: there are prospects of roundwood shortages, especially of softwoods, even to maintain current employment and cutting levels. Regenera- 